\title{
TOTAL FLAVONOID CONTENT ANALYSIS FOUR ILER ACCESSIONS (COLEUS ATROPURPUREUS [L] BENTH) ON LOWLAND KARANGANYAR, CENTRAL JAVA, INDONESIA
}

\author{
FITRIA ROVIQOWATI ${ }^{1}$, YULI WIDIYASTUTI ${ }^{2}$, SAMANHUDI ${ }^{3}$, AHMAD YUNUS ${ }^{3 *}$ \\ ${ }^{1}$ Department of Agronomy, Graduate School of Sebelas Maret University, Surakarta, Indonesia. ${ }^{2}$ Research and Development Center for \\ Medicinal Plant and Traditional Drug, Tawangmangu, Karanganyar, Central Java, Indonesia. ${ }^{3}$ Department of Agrotechnology, Faculty of \\ Agriculture, Sebelas Maret University, Surakarta, Indonesia. Email: yunus.uns7@yahoo.com
}

Received: 11 February 2019, Revised and Accepted: 20 May 2019

\section{ABSTRACT}

Objective: Iler is an ornamental plant that can be used as a medicinal plant. An effort to increase the flavonoids content was done by planting Iler in the lowlands with the hope that it can increase the secondary metabolites contained to meet the needs of flavonoids obtained from nature.

Methods: This research was conducted in Tegal Gedhe Village, Karanganyar Regency with an altitude of $182 \mathrm{~m}$ above sea level with Brown Mediterranean soil types. The study used a completely randomized block design. The treatment used consists of one factor which was four accessions of iler plants. Analysis of iler extract was done using ethanol, while analysis of thin layer chromatography (TLC) used the n-hexane:ethyl acetate (6:4) and analysis of total flavonoid were used the $\mathrm{AlCl}_{3}$ method using a spectrophotometer.

Results: The total extract content of iler plant in this study was not significantly different, which was accession 1 by $4.009 \%$ ( \pm 0.36 ), accession 2 by $5.677 \%$ ( \pm 0.25 ), accession 3 by $6.892 \%$ ( \pm 0.83 ), and accession 4 by $5.913 \%$ ( \pm 0.57$)$. TLC analysis shows that accession 1 and accession 2 had 8 spots, while accession 3 and accession 4 formed 9 spots. The highest total flavonoid content was found in accession 2 (5.848\% [ \pm 0.25$])$.

Conclusion: Accession 2 has a better morphology such as wider leaves characterized by higher source of flavonoids and longer vegetative life than the other three accessions.

Keywords: Flavonoid, Coleus atropurpureus, Iler accession, Medicinal plant, Lowland.

(C) 2019 The Authors. Published by Innovare Academic Sciences Pvt Ltd. This is an open access article under the CC BY license (http://creativecommons. org/licenses/by/4. 0/) DOI: http://dx.doi.org/10.22159/ajpcr.2019.v12i7.32513

\section{INTRODUCTION}

Iler (Coleus atropurpureus) is a plant that is easily propagated and commonly grows tropical area. The main utilization of iler plants is a medicinal material which contains flavonoids that can be used as an alternative in the development of herbal plants in the world.

Iler plants produce secondary metabolites in the form of steroids. In one research [1], pure isolates of steroids were obtained in the form of crystal needles with clear white color. The results of tests carried out using Liebermann-Burchard reagent resulted in the appearance of a green ring shape, indicating that secondary metabolites were found to be positive for steroids.

The research of Lisdawati et al. [2] stated that iler plants contained a class of chemical compounds in the form of terpenoids, tannins, catechin tannins, and flavonoids. The content of flavonoids has been proven to be used as antimalaria. Flavonoids in leaves act as a protection substance against ultraviolet (UV)-B rays, microbial infections, pigmentation, and contain antioxidants which is useful as drugs [3]. Furthermore, flavonoids can be used as prevention for cancer and coronary heart disease [4].

Another research Yohanes et al. [5] stated that the main content of secondary metabolites present in beluntas (Pluchea indica $\mathrm{L}$.) is flavonoids. The extract obtained was isolated using thin-layer chromatography, the obtained flavonoid compounds were flavonol compounds.

There are six main sub-classes of flavonoids, namely flavones (apigenin and luteolin), flavanone (naringenin and hesperidin), flavonol (quercetin and myricetin), catechins or flavanols (epicatechin and gallocatechin), isoflavones (genistein and daidzein), and anthocyanidin (cyanidin and pelargonidin). Flavonoids in plants are mostly in the form of sugar (glycosides), although they are sometimes found in the form of aglycones [6].

Flavonoids are able to counteract free radicals in Melissa officinalis extract [7]. This compound has a higher flavonoid content compared to four other tested plants. In Euphorbia neriifolia plants, there are a lot of flavonoid compounds which are characterized by chemical bonds that are formed 2-(3,4-dihidroxy-5-methoxy-phenyl)-3,5-dihydroxy-6,7dimethoxychromen-4,5-one. Flavonoids can be used as antioxidants to kill cancer cells and tumors [8].

The high flavonoids utilities in health requires more studies to be carried out to obtain the better sources of flavonoids from nature, as conducting research this research on iler plants which four iler accessions, to understand the accession that produces highest flavonoids that can be obtained as a medicine. This study aims to determine the flavonoid content of four accessions of iler plants grown in the lowlands.

\section{MATERIALS AND METHODS}

Plant material was obtained from four accessions of iler plants with violet leaf color, i.e. accession 1 (deep purple), accession 2 (greenish purple), accession 3 (green), and accession 4 (reddish purple). Leaves used for analysis were taken from leaf pairs to 1-10 each plant sample. In this study, all accessions used the same harvest criteria, which was $75 \%$ of the plant population which had flowered in each trial plot. 
Total extract content analysis

Leaf samples are cleaned from the dirt that attaches to the leaves and dried without direct sunlight exposure. Further drying was done by oven to absolute drying, then continued to be powered by mashing with the mortar until it smooth. Leaf extract which has been finely weighed $10 \mathrm{~g}$ was put into the bottle, added by $100 \mathrm{ml}$ ethanol into the bottle and shaked until homogeneous. The extract was left for $3 \times 24 \mathrm{~h}$ and then filtered to separate the pulp and filtrate. The results of the filtrate in the cup were evaporated using a water bath until it dries and weighed [9].

Total extract content can be calculated using formulas:

$$
r=\frac{x}{y} \times 100 \%
$$

Description:

$r$ : Total extract content

$x$ : Extract weight $(\mathrm{g})$

$y$ : Sample weight (g) [9].

\section{Thin-layer chromatography (TLC) analysis}

Iler plant leaves powder extract was weighed by $2 \mathrm{mg}$ and put into a small tub. n-hexane solution: ethyl acetate (6:4) as much as $200 \mu \mathrm{g}$ was put into the tub and stirred until it dissolves, and then followed by sonification for $15 \mathrm{~min}$. The solution was taken $2 \mu \mathrm{g}$ and attached to the plate. After eluent saturates, the plate with the solution was inserted into the chamber. After mobile phase was completed, verification process of sample content was done under UV light of $\lambda 254 \mathrm{~nm}$ and $366 \mathrm{~nm}[9]$.

\section{Flavonoid analysis}

1. Quercetin primary solution (400 ppm) was made by weighing $20 \mathrm{mg}$ of quercetin then dissolving it with $20 \mathrm{ml}$ ethanol and put it into a $50 \mathrm{ml}$ flask, then added with ethanol and transferred into the bottle

2. $10 \% \mathrm{AlCl}_{3}$ solution was made by weighing $10 \mathrm{~g}$ of $\mathrm{AlCl}_{3}$ and dissolving with $100 \mathrm{ml}$ of distilled water, then put into duran flask

3. $5 \%$ acetate acid solution was prepared. $2.6 \mathrm{ml}$ of acetate acid was put into a $50 \mathrm{ml}$ flask and added with aquadest, and then put into a bottle

4. $100 \mathrm{ppm}$ quercetin solution was made from $400 \mathrm{ppm}$ primary solution. $1 \mathrm{ml}$ of quercetin plus $1 \mathrm{ml}$ of $\mathrm{AlCl}_{3} 10 \%$ plus $1 \mathrm{ml}$ of $5 \%$ acetate acid was put into cuvet. The results were observed using a spectrophotometer at $\lambda 300-500 \mathrm{~nm}$. If the absorbance value is below 0.2 , the incubation is continued for $30 \mathrm{~min}$, and then the observation can be repeated. The result was recorded as the maximum wavelength $(\lambda)$

5. $1 \mathrm{ml}$ of quercetin plus $1 \mathrm{ml}$ of $\mathrm{AlCl}_{3}$ plus $1 \mathrm{ml}$ of acetate acid was added into the cuvette. Reading was done at $\lambda$ as before. The absorbance was recorded every $5 \mathrm{~min}$ for $40 \mathrm{~min}$. The most stable absorbance was recorded as the established operating time

6. $10 \mathrm{ml}$ of the solutions were made with a concentration of 100,120 , 140, 160, 180, and $200 \mathrm{ppm}$. Then, 2.5, 3, 3.5, 4, 4.5, and $5 \mathrm{ml}$ of $400 \mathrm{ppm}$ quercetin were taken and put it into a $10 \mathrm{ml}$ flask then transferred into duran flask. In each reading, $1 \mathrm{ml}$ of quercetin plus, $1 \mathrm{ml}$ of $\mathrm{AlCl}_{3}$ plus, and $1 \mathrm{ml}$ of $5 \%$ acetate acid were inserted into the cuvette. Measurement at $\lambda$ with established operating time which previously obtained. The results were analyzed regressively and recorded as established standard curve.

Sample preparation was done by weighing $100 \mathrm{mg}$ of sample. The sample dissolved with $10 \mathrm{ml}$ of ethanol. Sonification of the sample was done for $15 \mathrm{~min}$ then incubated overnight. Furthermore, $4 \mathrm{ml}$ sample was taken. Sample then evaporated in the oven at $50^{\circ} \mathrm{C}$ until it dries. $8 \mathrm{ml}$ of dried sample then dissolved with methanol. Another sonification was done for $15 \mathrm{~min}$ and the sample was left overnight. The sample was observed using a spectrophotometer at the determined wavelength and predetermined operating time. The blank solution contained $1 \mathrm{ml}$ of sample and $4 \mathrm{ml}$ of distilled water. The sample solution contains $1 \mathrm{ml}$ of sample plus, $1 \mathrm{ml}$ of $\mathrm{AlCl}_{3}$ plus, $2 \mathrm{ml}$ of $\mathrm{H}_{2} \mathrm{O}$ plus, and $1 \mathrm{ml}$ of acetate acid, then incubation was done for $15 \mathrm{~min}$ and the reading performed using a spectrophotometer [9].

The flavonoid content can be calculated using formula:

$$
Q E=\frac{c x V x f p \times 10^{-3}}{m} \times 100 \%
$$

Description

QE: The number of flavonoid content

$C$ : Equivalence of quercetin $(\mu \mathrm{g} / \mathrm{ml})$

$V$ : The total volume extracts $(\mathrm{ml})$

$f p$ : Dilution factor

$m$ : Sample weight $(\mathrm{mg})[9]$.

Data obtained from the observations were analyzed using the variance test ( $F$ test) at the level of $5 \%$. If there is a significant effect of the treatment tested based on F-count test at the level of $5 \%$, further testing will be done to see the differences between treatments with the Duncan test at the level of 5\%. Data analysis was processed using SPSS software.

\section{RESULTS}

The planting material used in this study was accession of iler plants with different leaf colors. Leaf color was observed using leaf color chart. Four accessions of the iler plants used were accession 1, accession 2, accession 3, and accession 4. Accession 1 has a leaf color of $5 \mathrm{RP} 3 / 2$, accession 2 has a leaf color $7.5 \mathrm{GY} 3 / 4$, and accession 3 has a leaf color 5 GY 5/6, while accession 4 has leaf color 2.5 R 4/2. Leaf appearance and leaf color are shown in Fig. 1.

Total extract content did not give a significantly difference in the accession of the iler plant. Accession 3 shows the highest extract level $6.892 \%( \pm 0.25)$, whereas accession 2 showed the lowest extract yield with $5.677 \%( \pm 1.51)$
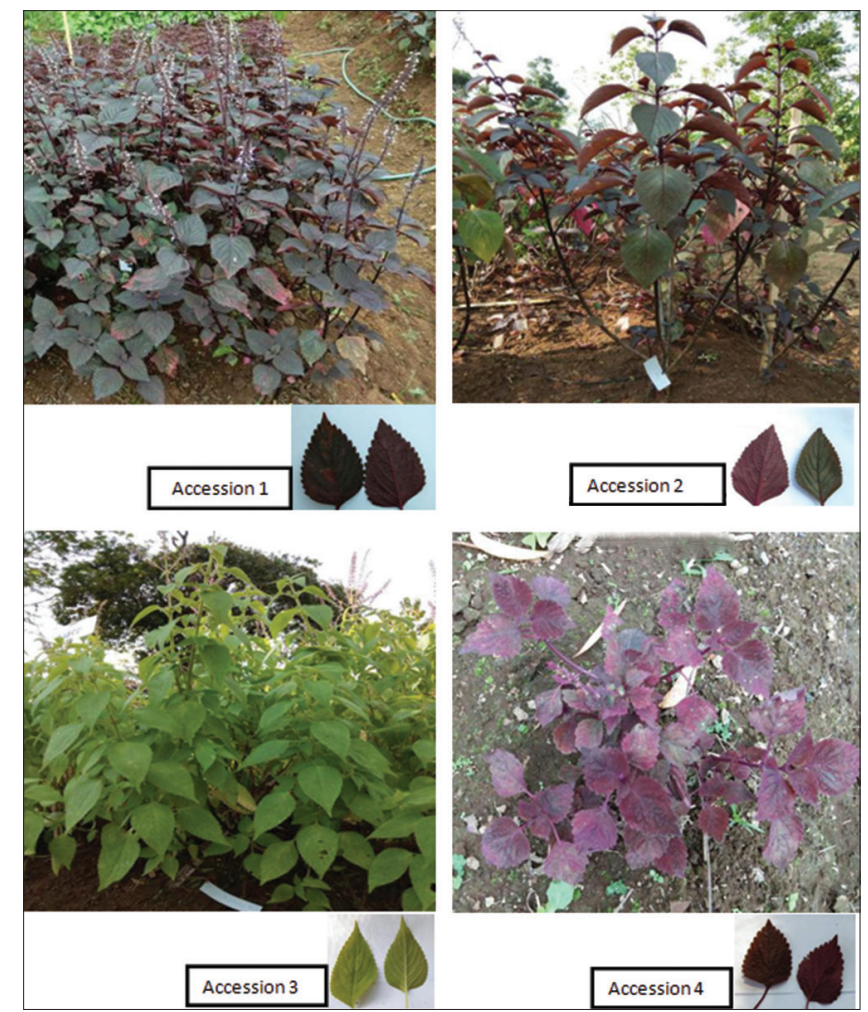

Fig. 1: The accession of four plants that are grown in lowland Karanganyar 
Isolation of flavonoid compounds on iler leaves was carried out using the TLC method. Extracts were dissolved with $96 \%$ ethanol and bottled along the plate using a micro pipette at a distance of $1 \mathrm{~cm}$ then eluted using n-hexane eluent:ethyl acetate (6:4) to produce the best separation in TLC.

Analysis of flavonoid content by spectrophotometer showed that total flavonoid significantly affected iler accession. Accession 2 produced the highest levels of total flavonoid 5.848\% $( \pm 0.25)$ while accession 4 showed the lowest levels of total flavonoid $3.451 \%( \pm 0.57)$.

\section{DISCUSSION}

The results of TLC (Fig. 2) were examined under UV light at the wavelengths by 255 and $366 \mathrm{~nm}$. Accession 1 and 2 formed 8 spots, while accession 3 and 4 formed 9 spots. The difference in the number of spots formed indicates that iler plants contain different amounts of active compounds. The clearer spot color is formed, it was indicating that the quality of the active compounds contained in the sample is good. All samples have almost the same Rf value (Table 1). The same Rf value means that the compounds contained in the iler accession have the same or similar characteristics. Different Rf values indicate there are differences in active compounds between accessions. In line with the research conducted by Alen et al. [10] in their study, it was stated that in TLC analysis of bamboo shoot extract (Schizostachyum brachycladum Kurz [Kurz]) on UV 255 and $366 \mathrm{~nm}$ showed the same Rf value. The results of the analysis show that the same Rf of 0.26 produces terpenoid compounds, especially the triterpenoid group.

n-hexane eluent:ethyl acetate (6:4) is suitable for TLC analysis of iler plant. In contrast to the research conducted by [11], TLC analysis of Carica papaya seeds using the same eluent obtained the best results with ratio of eluent $n$-hexane eluent:ethyl acetate $(20: 80)$. This means that the eluent ratio used for the TLC analysis depends on the sample used. Routine comparison commonly used in the analysis of flavonoids is quercetin [5], which has a yellow stain and has an Rf value of 0.64 .

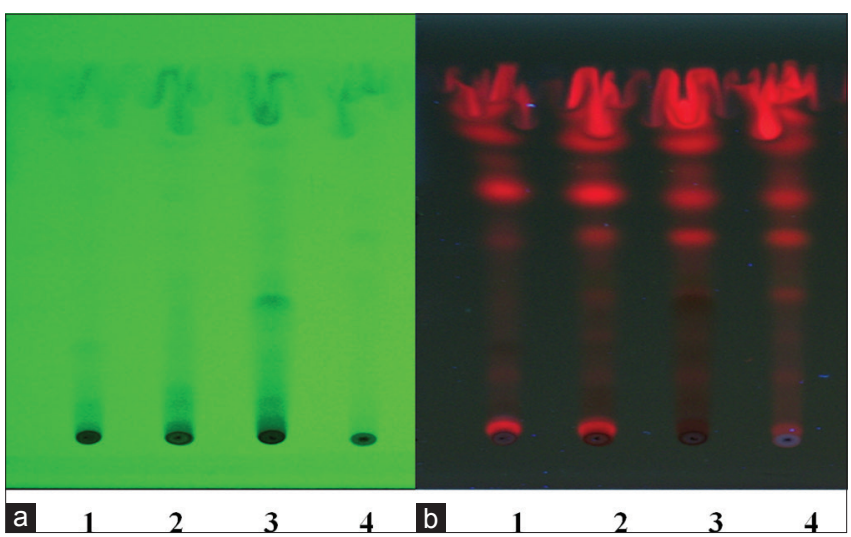

Fig. 2: The results of thin-layer chromatography of iler leaf extract with eluent $n$-hexane:ethyl acetate $(6: 4)$ with ultraviolet light $254 \mathrm{~nm}$ (a) and $366 \mathrm{~nm}$ (b), 1-4: number of accession
Quercetin is a biologically very strong, with antioxidant activity by 4.7 [12]. Quercetin can be used to protect the body from disease by preventing the occurrence of fat peroxidation.

Calculation of extract yield is the final weight ratio of the extract obtained with initial weight multiplied by $100 \%$. The extract of iler plant in this study was not significantly different, as shown by accession 1 with the value of $4.009 \%( \pm 0.23)$, accession 2 with $5.677 \%( \pm 0.21)$, accession 3 with $6.892 \%( \pm 0.25)$, and accession 4 with $5.913 \%( \pm 1.51)$ (Table 2). This might happen because the iler plants used in the study came from the same species so that the extracts in the 4 accessions were not significantly different. The extract itself is the result of the process of plant growth and the production of active compounds in plants. High biomass production does not determine of high extract yields. This is because the yield of plant extracts is a group of secondary metabolites.

Furthermore, Saifudin [13] explained that secondary metabolites are compounds synthesized by plants to as supplementary need, means that its production is needed but not as essential. This secondary metabolite compound is used in the field of pharmacology and biology as a drug.

The yield extracts added by ethanol solvents, as a study performed by Septiana and dan Asnani [14], showed that total flavonoids were not affected by the extraction method and the type of solvent used based on analysis result, it assumed that flavonoid compound had a similar polar and non-polar structure.

The results of total flavonoid content analysis in this study showed that the total flavonoid content produced by accession 1 was $4.009 \%$ $( \pm 0.36)$, accession 2 was $5.848 \%( \pm 0.25)$, and accession 3 was $4.971 \%$ $( \pm 0.83)$ while accession 4 was $3.451 \%( \pm 0.57)$ [Table 1]. This shows that accession 2 has the highest levels of flavonoids. Accession 2 has wider leaves than the other three accessions. Accession 2 has a longer flowering and harvesting age than three other accessions so that this accession is good to be cultivated and used as a flavonoid producing plant to meet the needs of flavonoids. Flavonoids are important because they are secondary metabolites that are useful as drugs. In line with the research conducted by Tari et al. [15] which states that the flavonoids contained in iler extract can accelerate wound healing in the skin of mice.[16]. Further stated that ethanol in the iler extract had antidiabetic activity in mice.

Iler plant in the lowland of Karanganyar have a various content of flavonoids, which may influenced by biotic or abiotic factors [17]. It was known that biotic and abiotic conditions can affect the growth and yield of plant secondary metabolites, in example, the effect of climate change on the presence of pollinators such as butterflies, bees and the effect on soil affect the productivity of plant metabolites. Another factor affecting flavonoids is growth hormone [18], as quercetin levels obtained from the extraction of Pluchea lanceolata plants contain NAA (auxin) + BAP (cytokinin).

In the article written by Sharanappa and Vidyasagar [19], flavonoid compounds were found in the leaves of the Argemone mexicana plant.

Table 1: The results of the retention factor analysis of thin-layer chromatography with $n$-hexane eluent:ethyl acetate (6:4)

\begin{tabular}{|c|c|c|c|c|c|c|c|}
\hline \multicolumn{2}{|c|}{ Accession 1} & \multicolumn{2}{|c|}{ Accession 2} & \multicolumn{2}{|c|}{ Accession 3} & \multicolumn{2}{|c|}{ Accession 4} \\
\hline Rf & Color & $\mathbf{R f}$ & Color & $\mathbf{R f}$ & Color & $\mathbf{R f}$ & Color \\
\hline 0.24 & Light brown & 0.24 & Light brown & 0.24 & Light brown & 0.24 & light brown \\
\hline 0.29 & Light brown & 0.29 & Light brown & 0.28 & Light brown & 0.29 & Light brown \\
\hline 0.36 & Light brown & 0.36 & Light brown & 0.34 & Light brown & 0.34 & Light brown \\
\hline 0.44 & Yellow & 0.44 & Yellow & 0.44 & Light brown & 0.42 & Light brown \\
\hline 0.54 & Yellow & 0.55 & Yellow & 0.48 & Yellow & 0.46 & Yellow \\
\hline 0.63 & Dark green & 0.62 & Dark green & 0.54 & Yellow & 0.54 & Yellow \\
\hline 0.7 & Green & 0.69 & Green & 0.61 & Dark green & 0.62 & Dark green \\
\hline \multirow[t]{2}{*}{0.74} & Green & 0.73 & Green & 0.68 & Green & 0.67 & Green \\
\hline & & & & 0.72 & Green & 0.72 & Green \\
\hline
\end{tabular}

Rf: Retention factor 
Table 2: Total extract content, thin-layer chromatography spot appearance and flavonoid content of four accession iler plant

\begin{tabular}{llll}
\hline $\begin{array}{l}\text { Number of } \\
\text { accession }\end{array}$ & $\begin{array}{l}\text { Total extract } \\
\text { content (\%) } \pm \text { SD }\end{array}$ & $\begin{array}{l}\text { TLC } \\
\text { (spots) }\end{array}$ & $\begin{array}{l}\text { Flavonoid } \\
\text { content (\%) } \pm \text { SD }\end{array}$ \\
\hline 1 & $6.197^{\mathrm{a}} \pm 0.23$ & 8 & $4.009^{\mathrm{a}, \mathrm{b}} \pm 0.36$ \\
2 & $5.677^{\mathrm{a}} \pm 0.21$ & 8 & $5.848^{\mathrm{c}} \pm 0.25$ \\
3 & $6.892^{\mathrm{a}} \pm 0.25$ & 9 & $4.971^{\mathrm{b}, \mathrm{c}} \pm 0.83$ \\
4 & $5.913^{\mathrm{a}} \pm 1.51$ & 9 & $3.451^{\mathrm{a}} \pm 0.57$ \\
\hline
\end{tabular}

The number followed by same character in a same column is not significantly different within Duncan test of 5\% level. TLC: Thin-layer chromatography, SD: Standard deviation

Argemone mexicana leaves contain a lot of cysteine flavonoids which useful as anti-inflammatory and analgesic activity. Total flavonoids can be used as analgesic drugs [20]. Furthermore, the extracts were containing lots of phenol compounds and flavonoids have strong antioxidants and have the potential to reduce sugar in blood [21].

\section{CONCLUSION}

Accession 1 and 2 formed 8 spot, while accession 3 and 4 formed 9 spots under the TLC analysis. The extract of iler plant in this study was not significantly different, with value of $4.009 \%( \pm 0.36)$ for accession 1 , accession 2 with 5.677\% $( \pm 0.25)$, accession 3 with $6.892 \%( \pm 0.83)$, and accession 4 with $5.913 \%( \pm 0.57)$. The highest total flavonoids were found in accession 2 (5.848\% $[ \pm 0.25])$. Accession 2 has a better morphology such as wider leaves characterized by higher source of flavonoids and longer vegetative life than the other three accessions.

\section{ACKNOWLEDGMENT}

This research was financially supported by Sebelas Maret University. The authors would like to thank Dr. Yuli Widiyastuti as field supervisor from Research and Development Center for Medicinal Plant and Traditional Drug, Tawangmangu, Karanganyar who provided the seeds of iler and flavonoid analysis.

\section{AUTHORS' CONTRIBUTIONS}

Fitria Roviqowati conducted the experiment and prepared the manuscript. Dr. Yuli Widiyastuti contributed in the experimental conduct and flavonoid analysis. Prof Samanhudi designed the experiment and finalizes the manuscript. Prof Ahmad Yunus designed and conducted the experiment and finalize the manuscript.

\section{CONFLICTS OF INTEREST}

All authors confirm that has no conflicts of interest this article content.

\section{REFERENCES}

1. Nurul AQ, Djangi AN, Muhaedah J. Isolation and identification of secondary metabolite compounds chloroform of iler leaves extract (Coleus scutellarioides, Linn, Benth). J Chem 2017;18:48-55.

2. Lisdawati V, Mutiatikum D, Alegantina S, Astuti Y. Characterization of miana leaves (Plectranthus scutellarioides (L.) Benth.) and physically, and chemical sirih fruit (Piper betle L.) from local antimalarial potions in North Sulawesi. Media Litbang Kesehatan 2008;18:213-25.

3. Harborne JB, Williams CA. Advances in flavonoid research since 1992. Phytochemistry 2000;55:481-504.

4. Yao LH, Jiang YM, Shi J, Tomás-Barberán FA, Datta N, Singanusong R, et al. Flavonoids in food and their health benefits. Plant Foods Hum Nutr 2004;59:113-22.

5. Yohanes AK, Fatimawati F, Wiyono WI. Isolation and identification of flavonoid compounds in beluntas leaves (Pluchea indica L.). Pharmacon 2015;1:42-57.

6. Ross JA, Kasum CM. Dietary flavonoids]: Bioavailability, metabolic effects, and safety. Annu Rev Nutr 2002;22:19-34.

7. Pourmorad F, Hosseinimehr SJ, Shahabimajd N. Antioxidant activity, phenol and flavonoid contents of some selected Iranian medicinal plants. Afr J Biotechnol 2006;5:1142-5.

8. Sharma V, Pracheta J. Extraction, isolation and identification of flavonoid from Euphorbia neriifolia leaves. Arabian J Chem 2017;10:509-14.

9. B2P2TOOT. Analysis of Flavonoid. Instrument Laboratory Procedure B2P2TOOT. Tawangmangu: Research and Development Center for Medicinal Plant and Traditional Drug; 2018.

10. Alen Y, Agresa FL, Yuliandra Y. Thin layer chromatography (TLC) analysis and antihyperuricemic activity of bamboo shoots extract Schizostachyum brachycladum Kurz (Kurz) in male white mice. J Sains Farm Klin 2017;3:146-52.

11. Khor ES, Wong NK. Potential antioxidant and cytotoxic properties of secondary metabolite extracts from Carica papaya fruits and seeds. Int J Pharm Pharm Sci 2014;7:220-24.

12. Sunyoto AA. Isolation and identification flavonoids rhizome of lengkuas merah (Alpinia galanga, Linn) by thin layer chromatography. CERATA J Pharm Sci 2013;4:20-30

13. Saifudin A. Natural Compounds of Secondary Metabolites: Theories, Concepts and Purification Techniques. Yogyakarta: Deepublish Publisher; 2014.

14. Septiana AT, dan Asnani A. The study of phytochemical properties of brown seaweed extract Sargassum duplicatum using a variety of solvents and methods of extraction. J Agrointek 2012;6:22-8.

15. Tari R, Posangi J, Wowor PM. Test of leaves iler effect (Coleus atropurpureus [L.] Benth.) on healing incision wounds on Rabbit skin (Oryctolagus cuniculus). J e-Biomedik (eBM) 2013;1:581-6.

16. Susilawati Y, Muhtadi A, Moektiwardoyo M, Arifin PC. Antidiabetes activity of iler leaves ethanol extracts (Plectranthus scutellarioides (L.) R.Br.) on white wistar rats with aloksan induction method. J Farmaka 2016;14:82-96.

17. Thakur M, Bhattacharya S, Khosla PK, Puri S. Improving production of plant secondary metabolites through biotic and abiotic elicitation. J Appl Res Med Aromat Plants 2019;12:1-12.

18. Arya D, Panti V, Kant U. In vitro propagation and quercetin quantification in callus cultures of Rasna (Pluchea lanceolata oliver and hiern). Indian J Biotechnol 2008;6:383-7.

19. Sharanappa R, Vidyasagar GM. Plant profile, phytochemistry and pharmacology of Argemone mexicana linn. A review. Int J Pharm Pharm 2014;7:46-53.

20. Ruslin M, Akbar FH, Hajrah YA, Subehan S. Analysis of total flavonoid levels in brown algae (Sargassum sp. and Padina sp.) as analgesic drug therapy. Asian J.Pharm and Clin Res 2018;11:81-3.

21. Biswas R, Sen KK. Pharmacognostical evaluation, in vitro antioxidant effects of Syzygium cumini Linn. Seed extract, and the potential role of this extract as hypoglycemic agent in alloxan-induced diabetic rats. Asian J Pharm Clin Res 2018;11:155-60. 